\title{
Association of explanatory histological findings and urinary protein and serum creatinine levels at renal biopsy in lupus nephritis: a cross-sectional study
}

Eri Katsuyama ${ }^{1 \dagger}$, Yoshia Miyawaki $^{1,2+}$, Ken-ei Sada ${ }^{1 *+} \mathbb{D}$, Yosuke Asano ${ }^{1}$, Keigo Hayashi ${ }^{1}$, Yuriko Yamamura ${ }^{1}$, Sumie Hiramatsu-Asano ${ }^{1}$, Michiko Morishita ${ }^{1}$, Keiji Ohashi', Haruki Watanabe', Takayuki Katsuyama', Mariko Narazaki ${ }^{1}$, Yoshinori Matsumoto ${ }^{1}$ and Jun Wada ${ }^{1}$

\begin{abstract}
Background: The aim of the present study was to evaluate the association between the histology of active and chronic lesions and urinary protein and serum creatinine $(\mathrm{SCr})$ levels, as common clinical endpoints in clinical trials for lupus nephritis (LN).

Methods: In total, 119 patients diagnosed with LN class III, IV, and V, as defined by the International Society of Nephrology/Renal Pathology Society, between 1990 and 2015, were enrolled in the present study. Multiple regression analysis was performed to explore semi-quantitative histological variables associated with urinary protein and SCr levels.

Results: The mean age of the enrolled patients was 45 years, and $79 \%$ were female. The mean $\mathrm{SCr}$ and mean urinary protein levels at the time of renal biopsy were $0.87 \mathrm{mg} / \mathrm{dl}$ and $3.00 \mathrm{~g} / \mathrm{gCr}$, respectively. Class IV (71\%) was the most common type of LN followed by class III (17\%), and class V (13\%). Multicollinearity was confirmed between monocellular infiltration (variance inflation factor $[\mathrm{VIF}]=10.22$ ) and interstitial fibrosis $(\mathrm{VIF}=10.29)$, and between karyorrhexis $(\mathrm{VIF}=4.14)$ and fibrinoid necrosis $(\mathrm{VIF}=4.29)$. Fibrinoid necrosis and monocellular infiltration were subsequently excluded, and multiple regression analysis revealed that only the urinary protein level was correlated with wire loop lesions ( $\beta$-coefficient [ $\beta]$ : 1.09 and confidence interval [CI]: 0.35 to 1.83), and that the SCr level was correlated with glomerular sclerosis ( $\beta$ : 1.08 and Cl: 0.43 to 1.74).
\end{abstract}

Conclusion: As urinary protein and SCr levels were not quantitatively associated with active lesions, they may not accurately reflect the response to remission induction therapy in patients with LN.

Keywords: Lupus nephritis, Active lesions, Chronic lesions, Urinary protein, Serum creatinine

\footnotetext{
* Correspondence: sadakenn@md.okayama-u.ac.jp

tEri Katsuyama, Yoshia Miyawaki, Ken-ei Sada are contributed equally to this work.

'Department of Nephrology, Rheumatology, Endocrinology and Metabolism, Okayama University Graduate School of Medicine, Dentistry and Pharmaceutical Sciences, 2-5-1 Shikata-cho, Kitaku, Okayama 700-8558, Japan Full list of author information is available at the end of the article
}

(C) The Author(s). 2020 Open Access This article is licensed under a Creative Commons Attribution 4.0 International License, which permits use, sharing, adaptation, distribution and reproduction in any medium or format, as long as you give appropriate credit to the original author(s) and the source, provide a link to the Creative Commons licence, and indicate if changes were made. The images or other third party material in this article are included in the article's Creative Commons. licence, unless indicated otherwise in a credit line to the material. If material is not included in the article's Creative Commons licence and your intended use is not permitted by statutory regulation or exceeds the permitted use, you will need to obtain permission directly from the copyright holder. To view a copy of this licence, visit http://creativecommons.org/licenses/by/4.0/. The Creative Commons Public Domain Dedication waiver (http://creativecommons.org/publicdomain/zero/1.0/) applies to the data made available in this article, unless otherwise stated in a credit line to the data. 


\section{Background}

While clinical trials for promising therapeutic agents for lupus nephritis (LN), such as B cell targeted therapy, cytokine-targeted therapy (IL-6 and IFN-a), and cytotoxic $\mathrm{T}$ lymphocyte-associated antigen 4 , have been conducted, none have shown improved outcomes compared with controls [1]. These failures may be attributed to inadequate inclusion criteria, study populations, sample sizes, and study duration [1, 2]. Furthermore, one study focused on the definition of outcome measurements [3, 4].

Proteinuria and serum creatinine ( $\mathrm{SCr}$ ) have been considered as promising predictors for renal prognosis in patients with LN [5-8]. Consequently, the primary outcome of the majority of clinical studies for LN is defined by urinary protein and SCr levels $[9,10]$. Previous studies have revealed that measures of chronic lesions in $\mathrm{LN}$, such as the chronic index, glomerular sclerosis, and interstitial fibrosis, are related to a poor renal outcome $[11,12]$. The estimated glomerular filtration rate (eGFR) is calculated using the SCr level, and eGFR and proteinuria are biomarkers for the classification of chronic kidney disease [13]. Therefore, proteinuria and the $\mathrm{SCr}$ level at renal biopsy may reflect chronic but not active lesions, which may respond to immunosuppressive treatment, and may serve as prognostic predictors for LN.

The main objective of this study was to explore the histology of active and chronic lesions, as well as their association with proteinuria and $\mathrm{SCr}$ level, in patients with LN.

\section{Methods}

\section{Study design, setting, and population}

We retrospectively reviewed patients with LN at Okayama University Hospital. Data from 1990 to 2006 and 20072015 were collected from paper- and electronic-based records, respectively. Data collection was completed in 2016-2017. The enrolled patients fulfilled the 1997 American College of Rheumatology revised criteria for the classification of systemic lupus erythematosus (SLE) [14]. Patients were eligible for participation in this study if they had a histologically confirmed diagnosis of LN (class III, IV, or V) according to the International Society of Nephrology/Renal Pathology Society (ISN/RPS) classification [15]. Eligible patients were followed up from their first renal biopsy for 10 years, until December 2015.

\section{Clinical parameters}

The following information was collected at the time of the renal biopsy, prior to treatment: age, sex, SLE disease activity index 2000, daily maximum dose of prednisolone, use of immunosuppressants, $\mathrm{SCr}$ and eGFR levels, urinary protein levels $(\mathrm{g} / \mathrm{gCr})$, hematuria (dipstick test $>2+$ and $>5$ erythrocytes per high power field), and active urine sediments. The eGFR was evaluated by the equation developed by the Japanese Society of Nephrology [16].

\section{Histological parameters}

For all participants, the histology of the first renal biopsy sample was classified according to the ISN/RPS classification by experienced nephrologists and/or pathologists. Active glomerular lesions were defined by the presence of endocapillary hypercellularity, leukocyte infiltration, subendothelial hyaline deposits, interstitial inflammation, karyorrhexis, fibrinoid necrosis, and cellular crescent formation. Active interstitial lesions were defined by monocellular infiltration. Chronic glomerular lesions were defined by glomerular sclerosis, fibrosis adhesion, and fibrous crescent formation, whereas chronic interstitial lesions were defined by interstitial fibrosis. Arteriosclerosis was also defined by chronic lesions. Each renal biopsy sample was processed using light and immunofluorescence microscopy with standard methods of fixation and staining. For semi-quantitative analysis, the histological score was calculated as described in our previous study [17], where histological score $=(0.5 \times$ number of glomeruli with segmental lesions $+1 \times$ number of glomeruli with global lesions)/total number of glomeruli. Interstitial lesions such as interstitial fibrosis, arteriosclerosis, and monocellular infiltration to interstitial, tubular, and vascular lesions were semi-quantitatively graded on a scale of $0,1,2$, and 3 (absent, mild, moderate, and severe, respectively). Interstitial lesions were categorized as high- or low-grade according to a cutoff score of 2 .

\section{Outcomes}

The primary outcome measures were the urinary protein and SCr levels. The secondary outcome measure was the cumulative 10-year renal survival rates from the date of the renal biopsy. The renal endpoint was defined as > $40 \%$ decline in the eGFR.

\section{Statistical analysis}

Statistical analyses were performed using JMP ${ }^{\oplus} 14$ software (SAS Institute Inc., Cary, NC, USA) and STATA v15 (StataCorp, College Station, TX, USA). All statistical tests were 2-sided. $p<0.05$ was considered to indicate a statistically significant difference. Complete case analyses were performed, excluding patients with missing clinical data at the time of the first biopsy. The descriptive statistics are expressed as the mean and standard deviation (SD) for continuous variables, and as $\mathrm{n}$ (\%) for categorical variables. The cumulative renal survival rates were calculated using Kaplan-Meier analysis. We censored patients that did not reach the renal endpoint when they completed the 10-year follow-up or at the date of the 
last recorded visit until December 31, 2015. We calculated the number of patients at risk for reaching the endpoint from the date of the renal biopsy. Patients were grouped according to urinary protein levels and the eGFR, and survival rates were assessed using log-rank tests.

Subsequently, multiple linear regression (ordinary least squares regression) analysis was performed to explore whether the histological findings contributed to urinary protein and $\mathrm{SCr}$ levels. The primary dependent variables were urinary protein and SCr levels at the time of renal biopsy, which were recorded as continuous variables, and the candidate variable was the renal histological score. Urinary protein levels were log-transformed to fulfill the assumption of a normal distribution of the residuals. To address multicollinearity, which was assessed using the variance inflation factor (VIF) $[18,19]$, we analyzed our data as two separate models excluding highly correlated covariates. We performed multiple linear regression analysis including age and sex for sensitivity analysis.

\section{Results}

\section{Patient characteristics at renal biopsy}

From a total of 158 patients with LN, 119 patients with ISN/RPS class III, IV, and/or V were enrolled in the present study after eliminating 11 patients with class I, II, or VI; 20 patients with a lack of clinical data; and eight patients who underwent a re-biopsy. Patient characteristics are shown in Table 1 . The mean age of the patients was 45 years, and $79 \%$ were female. The mean SCr level and eGFR were $0.87 \mathrm{mg} / \mathrm{dl}$ and $77.3 \mathrm{ml} / \mathrm{min} /$ $\mathrm{m}^{2}$, respectively, at the time of the first renal biopsy. The mean urinary protein level was $3.00 \mathrm{~g} / \mathrm{gCr}$. Forty-six (39\%) patients were treated with prednisolone alone and the others were treated with concomitant immunosuppressants for remission induction. Renal histology revealed that class IV (71\%) was the most common type, followed by class III (17\%) and class V (13\%). The mean (SD) scores of each histological lesion were as follows: endocapillary proliferation, $0.26(0.30)$; karyorrhexis, 0.06 (0.12); fibrinoid necrosis, 0.08 (0.14); rupture of the glomerular basement membranes, 0.01 (0.03); extracapillary proliferation, $0.05(0.10)$; wire loop lesions, 0.14 (0.27); hyaline deposits, 0.02 (0.06); membranous lesions, 0.11 (0.28); glomerular sclerosis, 0.11 (0.16); fibrous adhesions, 0.04 (0.07); and fibrous crescents, 0.01 (0.04). The proportions of monocellular infiltration, interstitial fibrosis, and arteriosclerosis with histological grade $\geq 2$ were 43 (36\%), 41 (34\%), and 23 (19\%), respectively. The Pearson's correlation coefficient for each histological lesion is presented in Supplementary Table 1.

During the mean observation period of 1931 days, 11 (9.2\%) patients experienced $a>40 \%$ decrease in eGFR.
Table 1 Patient characteristics at renal biopsy

\begin{tabular}{|c|c|c|c|}
\hline \multirow[t]{2}{*}{ Characteristic } & \multicolumn{2}{|l|}{ Total } & \multirow{2}{*}{$\begin{array}{l}\text { Missing } \\
\text { (\%) }\end{array}$} \\
\hline & $n=11$ & & \\
\hline Age, years & 45 & $( \pm 16)$ & - \\
\hline Sex, female, n (\%) & 94 & (79) & - \\
\hline Observation period, days & 2958 & $( \pm 2584)$ & - \\
\hline SLEDAI-2 K score & 16 & $( \pm 6)$ & 53.8 \\
\hline \multicolumn{4}{|l|}{ ISN/RPS classification } \\
\hline Class III, n (\%) & 20 & (17) & - \\
\hline Class III + V, n (\%) & 2 & (10) & - \\
\hline Class IV, n (\%) & 84 & (71) & - \\
\hline Class IV + V, n (\%) & 7 & (8) & 0.8 \\
\hline Class V, n (\%) & 15 & (13) & - \\
\hline Max dose of PSL, mg/day & 37 & $( \pm 15)$ & 5.0 \\
\hline $\begin{array}{l}\text { Immunosuppressive therapy } \\
\text { for remission induction }\end{array}$ & & & 4.2 \\
\hline PSL alone, n (\%) & 46 & (39) & \\
\hline Cyclophosphamide, n (\%) & 31 & (26) & - \\
\hline Tacrolimus or cyclosporine, n (\%) & 22 & (19) & - \\
\hline Mycophenolate mofetil, n (\%) & 13 & (11) & - \\
\hline Others, n (\%) & 2 & (2) & - \\
\hline Serum creatinine, mg/dl & 0.87 & $( \pm 0.51)$ & - \\
\hline $\mathrm{eGFR}, \mathrm{ml} / \mathrm{min} / \mathrm{m}^{2}$ & 77.3 & $( \pm 31.0)$ & - \\
\hline Urinary protein, $\mathrm{g} / \mathrm{gCr}$ & 3.00 & $( \pm 2.78)$ & - \\
\hline Hematuria (scale $>2+$ ), n (\%) & 52 & (44) & 2.5 \\
\hline Active urinary sediment, $\mathrm{n}(\%)$ & 77 & (65) & 4.2 \\
\hline
\end{tabular}

Data are presented as the mean and standard deviation in brackets. SLEDAI- $2 \mathrm{~K}$ Systemic Lupus Erythematosus Disease Activity Index 2000; ISN/RPS International Society of Nephrology/Renal Pathology Society; PSL Prednisolone; eGFR Estimated glomerular filtration rate

There was no significant difference in the renal 10-year survival rate among the patients divided into four categories of urinary protein levels (Fig. 1 (a): log-rank test, $p=0.37$ ). Similarly, the renal survival rate did not differ among patients stratified by SCr levels (Fig. 1 (b): $\log$ rank test, $p=0.88$ ).

\section{Explanatory histological variables for urinary protein levels (log-transformed)}

Multiple regression analysis was used to explore the explanatory variables related to urinary protein levels (Table 2, Model 1, mean VIF $=3.08$ ). Wire loop lesions emerged as an independent explanatory variable ( $\beta$-coefficient $[\beta]: 1.08$ and $95 \%$ confidence interval $[\mathrm{CI}]: 0.33$ to 1.82). Multicollinearity was confirmed between monocellular infiltration $(\mathrm{VIF}=10.22)$ and interstitial fibrosis $(\mathrm{VIF}=10.29)$, and between karyorrhexis $(\mathrm{VIF}=4.14)$ and fibrinoid necrosis $(\mathrm{VIF}=4.29)$. Therefore, fibrinoid necrosis and monocellular infiltration were excluded from subsequent multiple regression analysis (Table 2, Model 

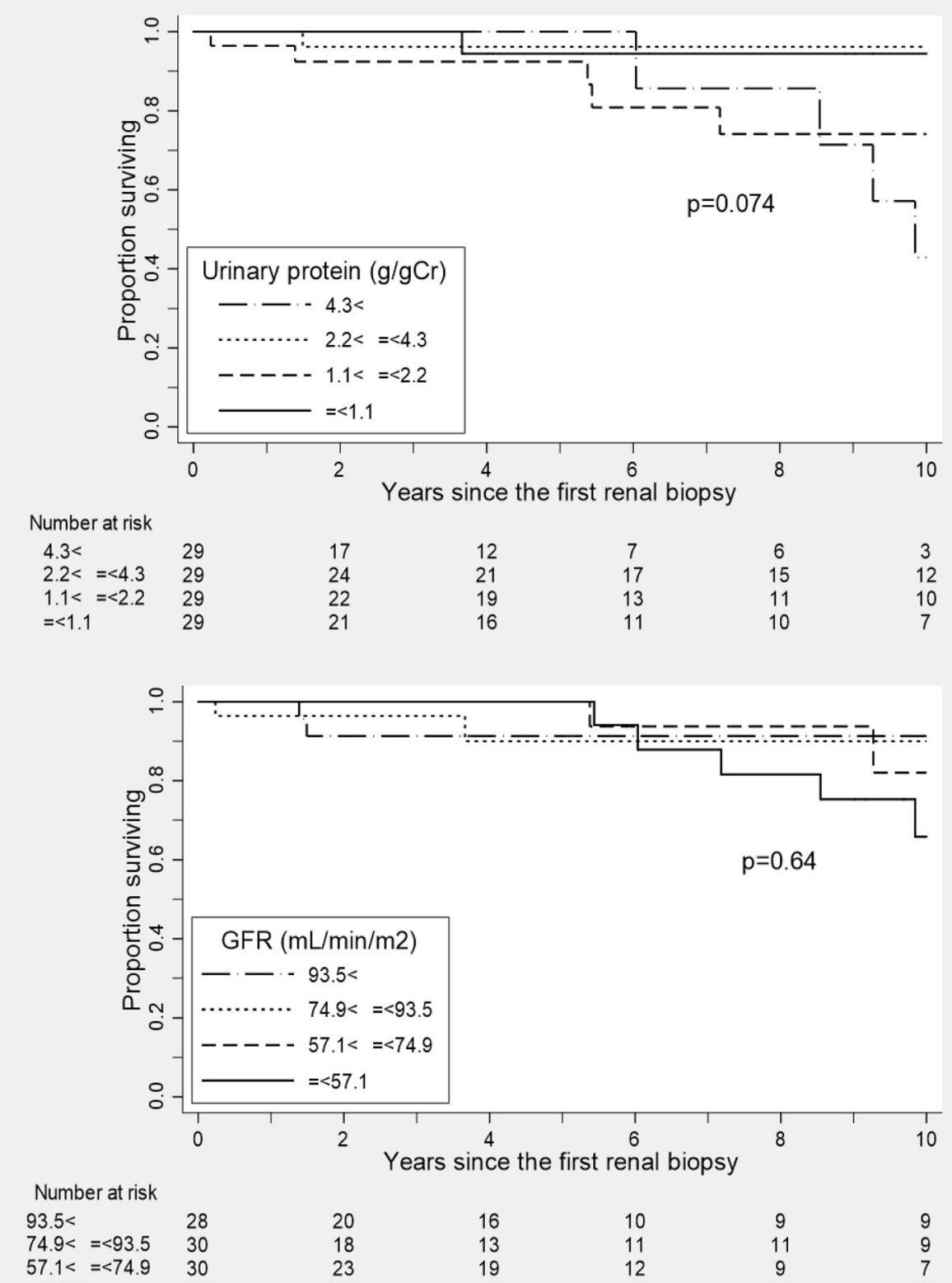

\begin{tabular}{|c|c|c|c|c|c|c|}
\hline \multicolumn{7}{|l|}{ Number at risk } \\
\hline $4.3<$ & 29 & 17 & 12 & 7 & 6 & 3 \\
\hline $2.2<=<4.3$ & 29 & 24 & 21 & 17 & 15 & 12 \\
\hline $1.1<=<2.2$ & 29 & 22 & 19 & 13 & 11 & 10 \\
\hline$=<1.1$ & 29 & 21 & 16 & 11 & 10 & 7 \\
\hline
\end{tabular}

Fig. 1 Cumulative renal survival rate of the enrolled patients, stratified according to (a) urinary protein levels and (b) estimated glomerular filtration rate (eGFR) at renal biopsy

2, mean VIF $=1.40)$. In Model 2, wire loop lesions $(\beta$ : 1.09 and $95 \%$ CI: 0.35 to 1.83 ) were also detected as an independent explanatory variable for proteinuria. When fibrinoid necrosis and interstitial fibrosis were excluded from the analysis in Model 3, wire loop lesions ( $\beta: 1.00$ and $95 \%$ CI: 0.28 to 1.71 ) were still detected as an independent explanatory variable (Table 2 , Model 3 , mean VIF $=1.40$ ). Sensitivity analysis including age and sex showed that only wire loop lesions were significantly related to proteinuria ( $\beta: 1.10$ and $95 \%$ CI: 0.35 to 1.85 in Model 2; $\beta$ : 1.01 and 95\% CI: 0.29 to 1.73 in Model 3) (Supplementary Table 2).

\section{Explanatory histological variables for serum creatinine levels}

Similarly to the analysis for urinary protein level, multiple regression analysis using all the histological variables was performed to explore the explanatory variables related to the SCr level (Table 3, Model 1, Mean VIF = 3.08). Hyaline deposits ( $\beta$ : -1.84 and $95 \% \mathrm{CI}:-3.64$ to -0.04 ) and glomerular sclerosis ( $\beta$ : 1.10 and $95 \% \mathrm{CI}$ : 0.43 to 1.76 ) emerged as independent explanatory variables in Model 1. After excluding fibrinoid necrosis and monocellular infiltration in Model 2, and fibrinoid necrosis and interstitial fibrosis in Model 3, glomerular 
Table 2 Multiple regression analysis of log-transformed urinary protein levels at renal biopsy and histological variables

\begin{tabular}{|c|c|c|c|}
\hline \multirow[t]{2}{*}{ Variable } & Model 1 & Model 2 & Model 3 \\
\hline & Coeff $[95 \% \mathrm{Cl}]$ & Coeff $[95 \% \mathrm{Cl}]$ & Coeff $[95 \% \mathrm{Cl}]$ \\
\hline \multicolumn{4}{|l|}{ Active lesions } \\
\hline Endocapillary proliferation & $0.66[-0.12$ to 1.44$]$ & $0.64[-0.13$ to 1.41$]$ & $0.67[-0.10$ to 1.43$]$ \\
\hline Karyorrhexis & $0.93[-2.11$ to 3.97$]$ & $0.87[-1.14$ to 2.87$]$ & $0.84[-1.16$ to 2.83$]$ \\
\hline Fibrinoid necrosis & $-0.12[-2.82$ to 2.58$]$ & & \\
\hline Rupture of glomerular basement membranes & $2.34[-5.52$ to 10.21$]$ & $2.26[-4.48$ to 9.00$]$ & $2.14[-4.60$ to 8.87$]$ \\
\hline Extracapillary proliferation & $1.79[-0.63$ to 4.22$]$ & $1.77[-0.62$ to 4.16$]$ & $1.84[-0.54$ to 4.22$]$ \\
\hline Wire loop lesions & $1.08[0.33$ to 1.82$]$ & $1.09[0.35$ to 1.83$]$ & $1.00[0.28$ to 1.71$]$ \\
\hline Hyaline deposits & $1.18[-2.65$ to 5.00$]$ & $1.12[-2.65$ to 4.89$]$ & $1.39[-2.34$ to 5.12$]$ \\
\hline Membranous lesions & $0.64[-0.07$ to 1.35$]$ & $0.67[-0.02$ to 1.35$]$ & $0.67[-0.01$ to 1.36$]$ \\
\hline $\begin{array}{l}\text { Monocellular infiltration } \\
\text { (category) }\end{array}$ & $-0.25[-1.48$ to 0.98$]$ & & $-0.07[-0.53$ to 0.39$]$ \\
\hline \multicolumn{4}{|l|}{ Chronic lesions } \\
\hline Glomerular sclerosis & $1.13[-0.28$ to 2.54$]$ & $1.15[-0.24$ to 2.54$]$ & $1.13[-0.24$ to 2.49$]$ \\
\hline Fibrous adhesion & $-0.40[-3.41$ to 2.62$]$ & $-0.35[-3.33$ to 2.63$]$ & $-0.25[-3.21$ to 2.71$]$ \\
\hline Fibrous crescents & $1.63[-3.93$ to 7.19$]$ & $1.60[-3.76$ to 6.95$]$ & $1.80[-3.56$ to 7.15$]$ \\
\hline Interstitial fibrosis (category) & $0.23[-1.01$ to 1.47$]$ & $0.00[-0.47$ to 0.47$]$ & \\
\hline Arteriosclerosis (category) & $0.15[-0.38$ to 0.68$]$ & $0.13[-0.39$ to 0.64$]$ & $0.17[-0.35$ to 0.68$]$ \\
\hline
\end{tabular}

Proteinuria was log-transformed to obtain a closer approximation to normal distribution. Covariates; Model 1: all independent explanatory variables; Model 2: explanatory variables excluding fibrinoid necrosis and monocellular infiltration; Model 3: explanatory variables excluding fibrinoid necrosis and interstitial fibrosis. Coeff $\beta$-Coefficient; $\mathrm{Cl}$ Confidential interval

Table 3 Multiple regression analysis of serum creatinine levels at renal biopsy and histological variables

\begin{tabular}{|c|c|c|c|}
\hline \multirow[t]{2}{*}{ Variable } & Model 1 & Model 2 & Model 3 \\
\hline & Coeff $[95 \% \mathrm{Cl}]$ & Coeff $[95 \% \mathrm{Cl}]$ & Coeff $[95 \% \mathrm{Cl}]$ \\
\hline \multicolumn{4}{|l|}{ Active lesions } \\
\hline Endocapillary proliferation & $0.15[-0.22$ to 0.51$]$ & $0.16[-0.20$ to 0.52$]$ & $0.16[-0.2$ to 0.52$]$ \\
\hline Karyorrhexis & $0.08[-1.34$ to 1.51$]$ & $0.20[-0.74$ to 1.15$]$ & $0.23[-0.71$ to 1.17$]$ \\
\hline Fibrinoid necrosis & $0.18[-1.08$ to 1.45$]$ & & \\
\hline $\begin{array}{l}\text { Rupture of glomerular } \\
\text { basement membranes }\end{array}$ & $0.16[-3.54$ to 3.85$]$ & $0.34[-2.83$ to 3.52$]$ & $0.39[-2.79$ to 3.56$]$ \\
\hline Extracapillary proliferation & $0.37[-0.77$ to 1.51$]$ & $0.40[-0.73$ to 1.52$]$ & $0.42[-0.7$ to 1.54$]$ \\
\hline Wire loop lesions & $0.13[-0.22$ to 0.48$]$ & $0.12[-0.22$ to 0.47$]$ & $0.08[-0.26$ to 0.42$]$ \\
\hline Hyaline deposits & $-1.84[-3.64$ to -0.04$]$ & $-1.78[-3.56$ to -0.00$]$ & $-1.67[-3.43$ to 0.09$]$ \\
\hline Membranous lesions & $-0.17[-0.50$ to 0.17$]$ & $-0.19[-0.51$ to 0.13$]$ & $-0.15[-0.48$ to 0.17$]$ \\
\hline Monocellular infiltration (category) & $0.22[-0.36$ to 0.80$]$ & & $0.26[0.04$ to 0.47$]$ \\
\hline \multicolumn{4}{|l|}{ Chronic lesions } \\
\hline Glomerular sclerosis & $1.10[0.43$ to 1.76$]$ & $1.08[0.43$ to 1.74$]$ & $1.07[0.43$ to 1.72$]$ \\
\hline Fibrous adhesion & $0.73[-0.69$ to 2.14$]$ & $0.68[-0.72$ to 2.08$]$ & $0.79[-0.61$ to 2.19$]$ \\
\hline Fibrous crescents & $-1.30[-3.91$ to 1.31$]$ & $-1.31[-3.84$ to 1.21$]$ & $-1.32[-3.84$ to 1.21$]$ \\
\hline Interstitial fibrosis (category) & $0.06[-0.52$ to 0.65$]$ & $0.27[0.05$ to 0.49$]$ & \\
\hline Arteriosclerosis (category) & $-0.04[-0.29$ to 0.21$]$ & $-0.02[-0.26$ to 0.23$]$ & $-0.02[-0.26$ to 0.23$]$ \\
\hline
\end{tabular}


sclerosis was still an independent explanatory variable (Table 3, mean VIF $=1.40$ in Model 2 and mean VIF $=$ 1.40 in Model 3). Sensitivity analysis including age and sex showed that glomerular sclerosis was a constant independent explanatory variable for $\mathrm{SCr}(\beta: 1.01$ and $95 \%$ CI: 0.37 to 1.66 in Model 2; $\beta: 1.01$ and $95 \%$ CI: 0.38 to 1.64 in Model 3) (Supplementary Table 3).

\section{Discussion}

In this study, we explored the associations between histological findings and urinary protein and SCr levels at renal biopsy. The urinary protein level was reflected only in wire loop lesions, whereas the SCr level was only correlated with glomerular sclerosis.

We could not confirm urinary protein and $\mathrm{SCr}$ levels as predictive factors for the renal outcome of patients with LN. As several previous reports showed that urinary protein and $\mathrm{SCr}$ levels are the main predictors for renal outcome [5-8], there is no doubt that they may serve as predictors of renal prognosis. As the patients in the present study had less severe disease and a shorter observation period than previously reported, urinary protein and $\mathrm{SCr}$ levels were unable to predict renal prognosis in the present study.

Urinary protein level mainly reflected wire loop, but not endocapillary or extracapillary, proliferative lesions in our study. Our previous report showed that only extracapillary proliferation was associated with poor renal predictors in active lesion [17]. To the best of our knowledge, the association between histological findings and proteinuria has not been fully established in patients with LN. Previous reports showed that the urinary protein level was related to the activity index [20,21], while another report showed that proteinuria was not correlated with activity and chronicity indices [22]. A previous study revealed that proteinuria was correlated with hyaline deposition [12]. Considering these results, the application of urinary protein levels as a biomarker of treatment response for active LN may be challenging.

The SCr level was the only factor indicative of glomerular sclerosis in our study. This finding is supported by previous studies showing that the $\mathrm{SCr}$ level mainly reflects chronicity in $\mathrm{LN}[12,17,22]$, and is correlated with renal interstitial lesions, sclerotic glomeruli, and tubular atrophy [23, 24]. Although the $\mathrm{SCr}$ level is a promising biomarker for renal prognosis in patients with LN, it was only associated with chronic lesions. Therefore, the SCr level, similar to the urinary protein level, may not be applicable as a biomarker of treatment response in patients with $\mathrm{LN}$ with active lesions.

The present study had certain limitations. Firstly, this is a cross-sectional study performed at renal biopsy; therefore, we were unable to evaluate whether urinary protein and $\mathrm{SCr}$ levels directly reflect the treatment response of active lesions. However, we concluded that $\mathrm{SCr}$ was unlikely to recover to a normal range if glomerular sclerosis was present. Secondly, we did not evaluate treatment effects related to outcomes. Treatment may be adjusted according to not only histological findings, but also urinary protein and renal function. As our patients exhibited a better renal outcome than previous reports [6], we may have underestimated the predictive power of proteinuria and renal function for renal outcome.

\section{Conclusions}

The present study revealed that urinary protein and $\mathrm{SCr}$ levels did not quantitatively reflect active lesions in LN. Therefore, they may not be adequate biomarkers for measuring the response to remission induction therapy in patients with LN. Comparing the changes in candidate biomarkers and histological findings before and after treatment may aid the identification of potential biomarkers for monitoring the treatment response.

\section{Supplementary information}

Supplementary information accompanies this paper at https://doi.org/10. 1186/s12882-020-01868-9.

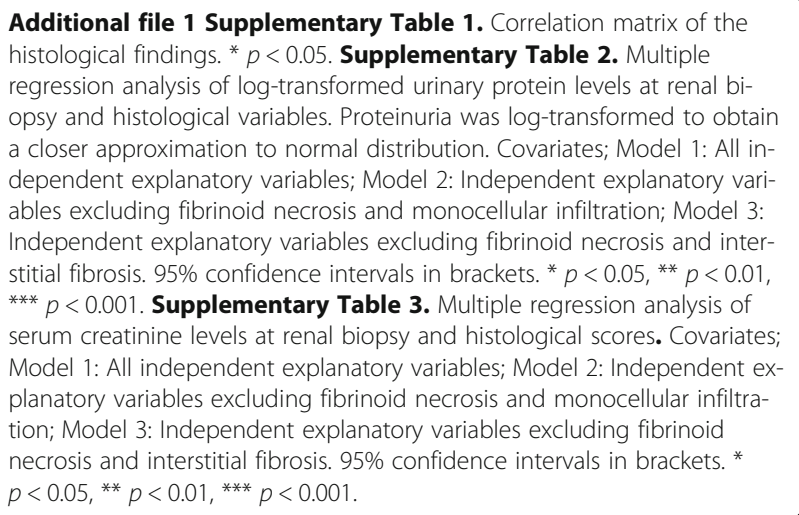

\section{Abbreviations}

LN: Lupus nephritis; SCr: Serum creatinine; eGFR: Estimated glomerular filtration rate; ISN/RPS: International society of nephrology/renal pathology society; SD: Standard deviation; VIF: Variance inflation factor; $\beta$ : $\beta$-Coefficient; $\mathrm{Cl}$ : Confidence interval

\section{Acknowledgements}

The authors would like to thank Mrs. Tomomi Maruyama for her significant assistance in data management.

\section{Authors' contributions}

EK, YM1, KS, YA, KH, YY, SHA, MM, KO, HW, TK, MN, and YM2 contributed to the conception and design of the study and data acquisition. EK, YM1, and KS conducted the analyses. EK, YM1, KS, and JW drafted the article and provided critical intellectual content. All authors have read and approved the final version of the manuscript.

\section{Funding}

No funding was received for this study. 


\section{Availability of data and materials}

The datasets used and/or analyzed during the current study are available from the corresponding author on reasonable request.

\section{Ethics approval and consent to participate}

This study was approved by the Ethics Committees of the Okayama University Graduate School of Medicine, Dentistry, and Pharmaceutical Sciences (authorization number: Ken 1905-017), and conducted according to the Declaration of Helsinki and the Ethical Guidelines for Medical and Health Research Involving Human Subjects in Japan. Patient consent was obtained using an opt-out approach.

\section{Consent for publication}

Not applicable.

\section{Competing interests}

JW has received speaking honoraria from Astellas, Boehringer Ingelheim, Daiichi Novartis, Sankyo, and Tanabe Mitsubishi, as well as grant support from Astellas, Bayer, Baxter, Chugai, Daiichi Sankyo, Kissei, Kyowa Hakko Kirin, MSD, Novartis, Novo Nordisk, Ono, Otsuka, Pfizer, Teijin, Torii, and Takeda. All other authors declare that they have no competing interests.

\section{Author details}

'Department of Nephrology, Rheumatology, Endocrinology and Metabolism, Okayama University Graduate School of Medicine, Dentistry and Pharmaceutical Sciences, 2-5-1 Shikata-cho, Kitaku, Okayama 700-8558, Japan 2Department of Healthcare Epidemiology, School of Public Health in the Graduate School of Medicine, Kyoto University, Kyoto, Japan.

Received: 13 December 2019 Accepted: 25 May 2020

Published online: 01 June 2020

\section{References}

1. Hruskova Z, Tesar V. Lessons learned from the failure of several recent trials with biologic treatment in systemic lupus erythematosus. Expert Opin Biol Ther. 2018:18(9):989-96.

2. Touma Z, Gladman DD. Current and future therapies for SLE: obstacles and recommendations for the development of novel treatments. Lupus Sci Med. 2017:4(1):e000239.

3. Corapi KM, Dooley MA, Pendergraft WF 3rd. Comparison and evaluation of lupus nephritis response criteria in lupus activity indices and clinical trials. Arthritis Res Ther. 2015;17:110.

4. Quintana LF, Jayne D. Sustained remission in lupus nephritis: still a hard road ahead. Nephrol Dial Transplant. 2016;31(12):2011-8

5. Dall'Era M, Cisternas MG, Smilek DE, Straub L, Houssiau FA, Cervera R, Rovin $\mathrm{BH}$, Mackay M. Predictors of long-term renal outcome in lupus nephritis trials: lessons learned from the euro-lupus nephritis cohort. Arthritis Rheumatol. 2015;67(5):1305-13

6. Ayodele OE, Okpechi IG, Swanepoel CR. Predictors of poor renal outcome in patients with biopsy-proven lupus nephritis. Nephrology (Carlton). 2010; 15(4):482-90.

7. Fine DM, Ziegenbein M, Petri M, Han EC, McKinley AM, Chellini JW, Nagaraja $\mathrm{HN}$, Carson KA, Rovin BH. A prospective study of protein excretion using short-interval timed urine collections in patients with lupus nephritis. Kidney Int. 2009;76(12):1284-8.

8. Mosca M, Tani C, Aringer M, Bombardieri S, Boumpas D, Brey R, Cervera R, Doria A, Jayne D, Khamashta MA, et al. European league against rheumatism recommendations for monitoring patients with systemic lupus erythematosus in clinical practice and in observational studies. Ann Rheum Dis. 2010;69(7):1269-74.

9. Chan TM, Li FK, Tang CS, Wong RW, Fang GX, Ji YL, Lau CS, Wong AK, Tong MK, Chan KW, et al. Efficacy of mycophenolate mofetil in patients with diffuse proliferative lupus nephritis. Hong Kong-Guangzhou nephrology study group. N Engl J Med. 2000;343(16):1156-62.

10. Furie R, Nicholls K, Cheng TT, Houssiau F, Burgos-Vargas R, Chen SL, Hillson $J$, Meadows-Shropshire S, Kinaszczuk M, Merrill JT. Efficacy and safety of abatacept in lupus nephritis: a twelve-month, randomized, double-blind study. Arthritis Rheumatol. 2014;66(2):379-89.

11. Obrisca B, Jurubita R, Andronesi A, Sorohan B, Achim C, Bobeica R,

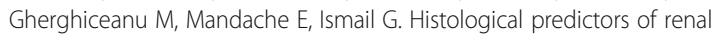

outcome in lupus nephritis: the importance of tubulointerstitial lesions and scoring of glomerular lesions. Lupus. 2018:27(9):1455-63.

12. Shariati-Sarabi Z, Ranjbar A, Monzavi SM, Esmaily H, Farzadnia M, Zeraati AA. Analysis of clinicopathologic correlations in Iranian patients with lupus nephritis. Int J Rheum Dis. 2013;16(6):731-8.

13. Johnson DW, Jones GR, Mathew TH, Ludlow MJ, Doogue MP, Jose MD, Langham RG, Lawton PD, McTaggart SJ, Peake MJ, et al. Chronic kidney disease and automatic reporting of estimated glomerular filtration rate: new developments and revised recommendations. Med J Aust. 2012;197(4):224-5.

14. Hochberg MC. Updating the American College of Rheumatology revised criteria for the classification of systemic lupus erythematosus. Arthritis Rheum. 1997;40(9):1725.

15. Weening JJ, D'Agati VD, Schwartz MM, Seshan SV, Alpers CE, Appel GB, Balow JE, Bruijn JA, Cook T, Ferrario F, et al. The classification of glomerulonephritis in systemic lupus erythematosus revisited. Kidney Int. 2004;65(2):521-30

16. Matsuo S, Imai E, Horio M, Yasuda Y, Tomita K, Nitta K, Yamagata K, Tomino Y, Yokoyama H, Hishida A, et al. Revised equations for estimated GFR from serum creatinine in Japan. Am J Kidney Dis. 2009;53(6):982-92.

17. Kojo S, Sada KE, Kobayashi M, Maruyama M, Maeshima Y, Sugiyama H, Makino $\mathrm{H}$. Clinical usefulness of a prognostic score in histological analysis of renal biopsy in patients with lupus nephritis. J Rheumatol. 2009:36(10):2218-23.

18. Fox JC, Prise KM. DNA lesions: linear energy transfer and radiosensitive mutants. BJR Suppl. 1992;24:48-52.

19. Schroeder MA. Diagnosing and dealing with multicollinearity. West J Nurs Res. 1990;12(2):175-84 discussion 184-177.

20. Hurtado A, Asato C, Escudero E, Stromquist CS, Urcia J, Hurtado ME, de La Cruz S, Wener MH, Zavala R, Johnson RJ. Clinicopathologic correlations in lupus nephritis in Lima, Peru. Nephron. 1999;83(4):323-30.

21. Appel GB, Silva FG, Pirani CL, Meltzer Jl, Estes D. Renal involvement in systemic lupud erythematosus (SLE): a study of 56 patients emphasizing histologic classification. Medicine (Baltimore). 1978;57(5):371-410.

22. Satirapoj B, Tasanavipas P, Supasyndh O. Clinicopathological correlation in asian patients with biopsy-proven lupus nephritis. Int J Nephrol. 2015;2015: 857316.

23. Parichatikanond $P$, Francis ND, Malasit $P$, Laohapand T, Nimmannit $S$, Singchoovong L, Nilwarangkur S, Chrirawong P, Vanichakarn S. Lupus nephritis: clinicopathological study of 162 cases in Thailand. J Clin Pathol. 1986;39(2):160-6.

24. Guo Q, Lu X, Miao L, Wu M, Lu S, Luo P. Analysis of clinical manifestations and pathology of lupus nephritis: a retrospective review of 82 cases. Clin Rheumatol. 2010:29(10):1175-80.

\section{Publisher's Note}

Springer Nature remains neutral with regard to jurisdictional claims in published maps and institutional affiliations.
Ready to submit your research? Choose BMC and benefit from:

- fast, convenient online submission

- thorough peer review by experienced researchers in your field

- rapid publication on acceptance

- support for research data, including large and complex data types

- gold Open Access which fosters wider collaboration and increased citations

- maximum visibility for your research: over $100 \mathrm{M}$ website views per year

At BMC, research is always in progress.

Learn more biomedcentral.com/submissions 